\title{
'N PSIGOMETRIESE OUDIT OP 'N BESTAANDE KEURINGSPROSEDURE
}

\author{
E CROSS \\ Departement Bedryfsielkunde \\ Universiteit van Stellenbosch \\ W MARAIS \\ Menslike Hulpbronne \\ Ou Mutual \\ H STEEL \\ Departement Sielkunde \\ Universiteit van Stellenbosch \\ CC THERON \\ Departement Bedryfsielkunde \\ Universiteit van Stellenbosch
}

\begin{abstract}
The validity and credibility of assertions on the efficiency and equity of selection procedures is dependent on the methodology with which the procedure was developed and justified. An ideal approach to the development and justification of a selection procedure was derived from standard guidelines and operationalized in the form of a comprehensive checklist. A psychometric audit on the developmental history of the selection procedure for the selection of commission advisors was undertaken. Various shortcomings were identified and rectified or recommendations were made on rectifying them. The audit found that the selection procedure had zero validity, negative utility and discriminated unfairly.
\end{abstract}

\section{OPSOMMING}

Die geldigheid en geloofwaardigheid van uitsprake oor die effektiwiteit en billikheid van ' $n$ keuringsprosedure is ' $n$ funksie van die metodologie waarmee die prosedure ontwikkel en regverdig is. ' $n$ Ideale benadering tot die ontwikkeling en regverdiging van ' $n$ keuringsprosedure is uit standaard riglyne afgelei en geoperasionaliseer in die vorm van ' $n$ omvattende kontrolelys. 'n Psigometriese oudit is onderneem op die ontwikkelingsgeskiedenis van ' $n$ keuringsprosedure vir die keuring van kommissie-adviseurs. Verskeie tekortkominge is geïdentifiseer en reggestel of aanbevelings ten opsigte van regstelling is gemaak. Die oudit het bevind dat die keuringsprosedure oor zero geldigheid beskik, negatiewe nutwaarde toon en onbillik diskrimineer.

\section{SYNOPSIS}

Informal observation seems to suggest that most South African organizations would be unable to justify their selection procedures in terms of efficiency and equity if challenged to do so by the Equal Employment Equity Act and/or The Bill on the Promotion of Equality and the Prevention of Unfair Discrimination. It thus seems important for South African organizations to proactively evaluate their selection procedures in terms of these two criteria and to timely correct substantive and/or procedural shortcomings. The validity and credibility of assertions on the efficiency and equity of selection procedures is dependent on the scientific rationality of the methodology with which the procedure was developed and justified. It thus becomes imperative that selection procedures should be evaluated against standard methodological guidelines. The evaluation of a selection procedure in essence involves a comparison between the actual developmental history of the procedure and a model approach derived from the aforementioned guidelines. Superimposing a methodological template on the actual process used to develop and justify a selection procedure would then expose any procedural and or substantive deficiencies. Such a process could be termed a psychometric audit. A psychometric audit was performed on the developmental history of a procedure for the selection of commission advisors. A comparison between the actual developmental history of the procedure and the ideal procedure, as operationalized in the form of a checklist, revealed serious procedural and substantive deficiencies. No validity, utility or fairness analysis was performed as part of the initial development procedure. Subsequent analyses performed as part of the audit revealed no significant relationship $(p>0,05)$ between any of the

Versoeke vir afskrifte moet gerig aan: CC Theron, Department Bedryfsielkunde, Universiteit van Stellenbosch, Privaatsak X1, Matieland, 7602 predictors and job performance. The procedure currently being used for the selection of commission advisors therefore should be regarded as discriminatory in as far as selection decisions are in effect being taken on arbitrary grounds. A significant difference $(p<0,05)$ in criterion performance was found between a historically advantaged white group and a historically disadvantaged black group of approximately $\mathrm{R} 4$ 000-00 per month. This most probably constitutes a legacy of apartheid, but could possibly also be explainable in terms of bias in the criterion measure. If valid predictor data would be interpreted fairly and criterion-referenced, such a situation will unavoidably result in adverse impact against the group who scores lower on the criterion, irrespective of the nature of the predictor distributions. This seems to again underline the need to identify learning potential amongst potential commission advisors from historically disadvantaged groups and to affirm, through accelerated development programmes, that the differences in the criterion distributions represent differences in attainments rather than dispositions. No significant relationship was found between gender or race and selection recommendations derived from any of the predictors. The irony consequently arises that there actually exists no prima facie grounds for unfair discrimination on which to call the de facto discriminatory selection procedure to account via litigation. Recommendations on improving the procedural and substantive deficiencies are made.

In Suid-Afrika opereer ondernemings in 'n ekonomiese omgewing wat ekstreme uitdagings en verantwoordelikheid aan hul stel. Suid-Afrika word tans gekenmerk deur 'n 29 persent werkloosheidkoers (gebaseer op 'n eng gedefinieerde arbeidsmark), en 'n jaarlikse ekonomiese groeikoers van minder as drie persent (Sidiropoulos, Jeffery, Mackay, Forgey, Chipps \& Corrigan, 1997). Die Instituut vir Toekomsnavorsing en die 
dokument GEAR (Growth, Employment and Redistribution) stel dit dat ' $n$ ekonomiese groeikoers van ten minste ses persent noodsaaklik is om werkloosheid konstant op 30 persent te handhaaf (Sidiropoulos et al., 1997). GEAR dui voorts dat sulke ekonomiese groei slegs bereik sal word deur kontinue verhogings in produktiwiteit. Suid Afrika is slegs 46ste op die internasionale mededingendheidsranglys (Sidiropoulos et al., 1997), weens swak produktiwiteit, wat verder ekonomiese groei via internasionale handel ondermyn. Die Arbeidsmark Kommissie het ' $\mathrm{n}$ verskeidenheid van interne en werksplekredes geïdentifiseer as oorsake vir Suid Afrika se lae produktiwiteit en lae ekonomiese groei. In hul samevattende gevolgtrekking oordeel die Arbeidsmark Kommissie dat die lae kwaliteit van werknemers een van die primêre oorsake van hierdie probleme is (Sidiropoulos et al., 1997).

Suid Afrikaanse ondernemings het ' $\mathrm{n}$ verantwoordelikheid teenoor hul eienaars/aandeelhouers om hul organisatoriese doelwitte van effektiwiteit, produktiwiteit en winsgewendheid te bereik (Milkovich \& Boudreau, 1994). In die strewe om hierdie doelwitte te bereik, is dit belangrik dat menslike hulpbronbestuur effektief toegepas word. Die effektiewe toepassing van menslike hulpbronbestuur behels twee tipes intervensies (Milkovich \& Boudreau, 1994). Eerstens die doeltreffende werwing, keuring en plasing sowel as bevordering en diensverlating van die onderneming se menslike hulpbronne, dus die regulering van die vloei van werknemers in, deur en uit die onderneming wat werksuksesvol/produktief in hul poste sal wees. Tweedens die instandhouding en ontwikkeling van die huidige menslike hulpbronvoorraad tot produktiewe werknemers, deur byvoorbeeld: prestasiebestuur, opleiding, motivering, vergoeding en arbeidsverhoudinge. Vir die ontwikkeling van menslike hulpbronne bly dit steeds belangrik dat werknemers gekeur is met die nodige potensiaal en vaardighede, wat suksesvol ontwikkel kan word. Dus moet menslike hulpbronbestuur nie net werknemers keur wat in hul onmiddellike poste werksuksesvol sal wees nie, maar ook in latere poste, binne die onderneming.

Ter ondersteuning van die bogaande argument het Bingham en Freyd (1926) al reeds 75 jaar gelede gevind dat: "the successful employee... does more work, does it better, with less supervision, with less interruption through absence... He makes fewer mistakes and has fewer accidents... He ordinarily learns more quickly, is promoted more rapidly, and stays with the company" (Cook, 1998, p.226).

Tiffin en Hull (in Cook, 1998) het in ' $\mathrm{n}$ verskeidenheid van studies bevind dat die beste werknemers in ' $n$ organisasie tot soveel as dubbeld die prestasie lewer as die swakste werknemers. Verdubbeling van produktiwiteit (drie persent ekonomiese groei na ses persent ekonomiese groei) is presies wat Suid Afrika nodig het en dit dui op die potensiële impak wat effektiewe keuring op produktiwiteit kan hê. Hunter en Schmidt (1995) ondersteun hierdie gevolgtrekking en het dit met meta-analise deurslaggewend bewys.

Die effektiwiteit van keuring is egter nie die enigste kriterium waarop ' $\mathrm{n}$ keuringsprosedure geëvalueer moet word nie. $\mathrm{Al}$ is ' $\mathrm{n}$ keuringsprosedure geldig kan dit ' $n$ ongelyke impak hê op die lede van die onderskeie subgroepe waaruit die applikantpopulasie bestaan (Milkovich \& Boudreau, 1994). Dit is dus ook noodsaaklik dat Suid Afrikaanse ondernemings verseker dat hul keuringsposedures nie nadelig op die lede van ' $n$ spesifieke subgroep impakteer nie. Weens Suid Afrika se diskriminerende geskiedenis is ' $\mathrm{n}$ aantal wette ingestel, om te verseker dat Suid Afrikaanse ondernemings billik keur (Wet op Gelyke Indiensnemingsgeleenthede,1998; Wet op die Bevordering van Gelykheid en Voorkoming van Onbillike Diskriminasie, 2000). Dit is dus belangrik om deurdagte aandag op keuring te fokus om te verseker dat dit prosedurieel en substantief billik geskied.
Die volgende wetgewing beïnvloed Suid Afrikaanse ondernemings deur billike keuring en indiensnemingspraktyke te vereis:

- Die Grondwet van die Republiek van Suid Afrika (1996);

- Die Wet op Gelyke Indiensnemingsgeleenthede (1998); en

- Die Wet op die Bevordering van Gelykheid en Voorkoming van Onbillike Diskriminasie (2000).

Die Wet op Gelyke Indiensnemingsgeleenthede, Hoofstuk II, Artikel 6(1) stel dit dat (Staatskoerant van die Republiek van Suid Afrika, 12 Oktober 1997, p.23):

No person may unfairly discriminate, directly or indirectly, against an employee, in any employment policy or practice, on one or more grounds, including race, gender, sex, pregnancy, marital status, family responsibility, ethnic or social origin, colour, sexual orientation, age, disability, religion, HIV status, conscience, belief, political opinion, culture, language and birth.

Die Wet op Gelyke Indiensnemingsgeleenthede geld ook vir aansoekers en is dit dus ' $n$ verdere rede waarom dit belangrik is dat die keuring billik diskrimineer. Indien die keuringsproses egter wel op gesigswaarde geoordeel onbillik diskriminerend van aard sou wees, kan die aansoeker 'n geregtelike saak instel teen die onderneming.

Die Wet op die Bevordering van Gelykheid en Voorkoming van Onbillike Diskriminasie ondersteun en brei verder uit op die Wet op Gelyke Indiensnemingsgeleenthede se verbod op onbillike diskriminasie in Hoofstuk 1, Artikel 1(xvii) en (xxvi). Verder stel die konsepwet in Hoofstuk 2, Deel C, Artikel 13(ii) dit dat (Staatskoerant van die Republiek van Suid Afrika, 12 Februarie 2000, p.11):

unfair discrimination' or 'to unfairly discriminate', in addition to the definition of "unfair discrimination" referred to in section 1 (xxvi), includes -

(a) any distinction, exclusion or restriction made on the basis of one or more of the prohibited grounds, or on any other ground which is aimed at or has the effect of impairing or nullifying the enjoyment or exercise by a person or group of persons, of employment opportunities;

(b) the failure to identify and take reasonable measures to remove any barriers to the full enjoyment of employment opportunities, by persons who were historically denied such opportunities by law or practice.

Eerstens verwys die wet daarna dat onbillike diskriminasie nie net diskriminasie op enige van die arbitrêre gronde is nie, maar ook as relevante gronde, dus gronde wat met werksukses verband hou, ' $n$ ongelyke impak op subgroepe het. Tweedens, indien ' $n$ onderneming in gebreke sou bly om beperkings op histories benadeelde groepe se indiensnemingsgeleenthede te identifiseer en te verwyder, sal dit volgens die voorgestelde wetgewing steeds as ' $\mathrm{n}$ diskriminerende praktyk beskou word. Onkunde oor onbillike diskriminasie sal dus nie ' $n$ verskoning wees nie en is dit dus belangrik om kundige advies in te win en keuring volgens algemeen aanvaarde standaarde/riglyne te ontwikkel en te evalueer. Artikel (14)(a)-(c) van die Wet op die Bevordering van Gelykheid en Voorkoming van Onbillike Diskriminasie, Deel C, stel dat agtergeblewe groepe nie onregverdig uitgesluit kan word deur advertensies, informele beperkings of keuringspraktyke, uit enige indiensnemingsgeleenthede nie. Dit is dus belangrik dat die hele indiensnemingsproses, vanaf werwing en posontleding tot by die finale keuringsbesluit, ondersoek moet word vir enige onbillike diskriminerende effekte.

Indien 'n aansoeker 'n saak op die gronde van onbillike diskriminasie wil instel teen ' $n$ onderneming, is slegs prima facie bewyse nodig dat die keuringsprosedure op gesigswaarde geoordeel wel onbillik diskrimineer. Die bewyslas lê dan by die 
onderneming om te bewys dat die prosedure in werklikheid nie onbillik diskrimineer nie. Dit is dus belangrik dat die onderneming proaktief verseker dat sy keuringsproses billik (sowel as effektief) is sodat, in die geval van geregtelike optrede, bewys kan word dat die keuringsproses aan die wetlike vereistes voldoen. Daar is reeds ' $n$ verskeidenheid van sake en presedente gestel in Amerika (kyk tabel 1), waar soortgelyke gelyke indiensnemingsgeleenthede wetgewing reeds ' $\mathrm{n}$ geruime tyd bestaan en ondernemings groot bedrae geld moes opoffer weens onbillike diskriminasie. Na verwagting sal Suid Afrika 'n soortgelyke pad volg en is dit nodig dat Suid Afrikaanse ondernemings voorbereid is hierop.

Suid Afrika het ' $\mathrm{n}$ geskiedenis van growwe diskriminasie en die agtergeblewe groepe is in ' $n$ benadeelde posisie by indiensneming, weens die beperkings op die agtergeblewe groepe se ontwikkelings- en indiensnemingsgeleenthede. Om die ongelykhede reg te stel het die menslike hulpbronbestuurder ' $n$ morele, sowel as ' $n$ wetlike verpligting om regstellende aksie toe te pas. Artikel 6(2)(a) van die Wet op Gelyke Indiensnemingsgeleenthede verwys daarna dat regstellende aksie 'n uitsondering op onbillike diskriminasie is. Suid Afrikaanse ondernemings het dus ' $n$ verpligting om hul keuringsprosedures sodanig te ontwikkel en te evalueer, dat regstellende aksie rasioneel geskied en aan die ekonomiese, wetlike en morele eise gestel aan Suid Afrikaanse ondernemings, voldoen.

tabel 1

Enkele Relevante Amerikaanse Hofsake

\begin{tabular}{|c|c|}
\hline Saak & Relevante Presedent \\
\hline Giggs v. Duke Power (1971) & $\begin{array}{l}\text { Afwesigheid van ' } n \text { diskriminerende } \\
\text { voorneme is geen verdediging nie; } \\
\text { werkgewer dra bewyslas. }\end{array}$ \\
\hline U.S. v. Georgia Power (1973) & $\begin{array}{l}\text { Valideringstrategieë moet volgens } \\
\text { standaard riglyne geskied. }\end{array}$ \\
\hline Dothard v. Rawlinson (1977) & Definieer indirekte diskriminasie. \\
\hline Connecticut v. Teal (1982) & $\begin{array}{l}\text { Besigheid moet verseker dat hele } \\
\text { keuringsprogram vry is van ongelyke }\end{array}$ \\
\hline \multicolumn{2}{|l|}{ impak. } \\
\hline $\begin{array}{l}\text { Watson v. Ft. Worth Bank \& } \\
\text { Trust (1988) }\end{array}$ & $\begin{array}{l}\text { Subjektiewe seleksie metodes (soos } \\
\text { onderhoude) moet op dieselfde wyse as } \\
\text { objektiewe toetse gevalideer word. }\end{array}$ \\
\hline \multicolumn{2}{|c|}{$\begin{array}{l}\text { (Basson, Christianson, Garbers, le Roux, Mischke \& Strydom, 1998; Cook, 1998; Gatewood } \\
\text { \& Feild, 1994) }\end{array}$} \\
\hline
\end{tabular}

Informele waarneming dui daarop dat meeste Suid Afrikaanse ondernemings nie hul keuringsprosedures in terme van effektiwiteit en billikheid kan regverdig nie. Sou Suid Afrikaanse ondernemings dus ingevolge die voorheen vermelde anti-diskriminasie bepalings vervat in die Wet op Gelyke Indiensnemingsgeleenthede en/of die Wet op die Bevordering van Gelykheid en die Voorkoming van Onbillike Diskriminasie, gedaag word om hul keuringsprosedures te regverdig, sou die meeste ondernemings nie oor die nodige psigometriese getuienis beskik om die effektiwiteit en billikheid van die keuringsprosedure aan te toon nie. Dit is daarom belangrik dat Suid Afrikaanse ondernemings hul keuringsprosedures evalueer volgens dié vereistes, en na gelang van tekortkominge aanpas. Die geldigheid en geloofwaardigheid van uitsprake oor die effektiwiteit en billikheid van die keuringsprosedure, is ' $n$ funksie van die metodologie waarmee die prosedure ontwikkel is en regverdig word. Dus is dit belangrik dat standaard riglyne ter ontwikkeling en evaluering van die keuringsprosedures ontwikkel en gebruik word tydens die evaluering van die keuringsprosedure. Die instansies soos aangedui in tabel 2 het reeds sodanige riglyne saamgestel ter ontwikkeling en evaluering van keuringsprosedures.
Die evaluering van ' $\mathrm{n}$ keuringsprosedure geskied in wese deur die ontwikkelingsgeskiedenis van die prosedure te vergelyk met die ideale benadering tot die ontwikkeling en regverdiging van 'n keuringsprosedure, afgelei uit die bogenoemde riglyne, om uiteindelik enige proseduriële en substantiewe tekortkominge te identifiseer en reg te stel. So ' $n$ proses sou beskryf kan word as 'n psigometriese oudit.

tabel 2

Riglyne Beskikbaar vir die Ontwikkeling en Evaluering van Keuringsprosedures

\begin{tabular}{|c|c|}
\hline Instansie & Riglyne/Benaderings \\
\hline $\begin{array}{l}\text { Society for Industrial Psychology } \\
\text { (SIP) }\end{array}$ & $\begin{array}{l}\text { Guidelines for the Validation and Use } \\
\text { of Assessment Procedures for the } \\
\text { Workplace (1998) }\end{array}$ \\
\hline $\begin{array}{l}\text { Psychometric Assessment Initiative } \\
\text { (PAI) }\end{array}$ & $\begin{array}{l}\text { Code of Practice for Psychological } \\
\text { Assessment (1998) }\end{array}$ \\
\hline $\begin{array}{l}\text { Society for Industrial-Organisational } \\
\text { Psychology (SIOP) }\end{array}$ & $\begin{array}{l}\text { Principles for the Validation and Use } \\
\text { of Personnel Selection Procedures } \\
\text { (1987) }\end{array}$ \\
\hline $\begin{array}{l}\text { Equal Employment Opportunity } \\
\text { Commission (EEOC) }\end{array}$ & $\begin{array}{l}\text { The Uniform Guidelines on Employee } \\
\text { Selection Procedures (1978) }\end{array}$ \\
\hline
\end{tabular}

\section{NAVORSINGSDOELWITTE}

Die primêre doel van die studie is om ' $\mathrm{n}$ psigometriese oudit te voltooi op ' $\mathrm{n}$ bestaande keuringsprosedure vir die keuring van kommissie-adviseurs.

Die sekondêre doelstellings onderliggend aan die primêre doelstelling is gevolglik om:

a) Die ideale benadering tot die ontwikkeling en regverdiging van 'n keuringsprosedure te beskryf, afgelei uit aanvaarde standaard riglyne ter ontwikkeling en evaluering van keuringsprosedures.

b) Uit die ideale benadering ' $n$ kontrolelys saam te stel vir die toekomstige ontwikkeling en evaluering van keuringsprosedures.

c) Die ontwikkeling, regverdiging en aard van die keuringsprosedure, vir die keuring van kommissie-adviseurs, kortliks te omskryf.

d) Aan die hand van die kontrolelys vas te stel tot welke mate die wyse waarop die bestaande keuringsprosedure ontwikkel en regverdig is met die ideale benadering, afgelei uit die standaard riglyne, ooreenstem.

e) Gevolglik enige proseduriële en substantiewe gebreke te identifiseer en reg te stel of ten minste aanbevelings ten opsigte van regstelling te maak.

\section{'N OORSIG VAN DIE PROSEDURE TER SPRAKE BY DIE ONTWIKKELING EN EVALUERING VAN KEURINGPROSEDURES}

Die doel met personeelkeuring is om waarde tot die onderneming toe te voeg deur die vlak van werksprestasie gelewer deur werknemers te verhoog, deur die kwaliteit van werknemers wat deur die onderneming beweeg, te verhoog. Die ideale keuringstrategie sou gevolglik wees om keuring direk op werksukses te baseer. Dit sou egter beteken dat werksukses (Y) ten tye van die keuringsbesluit gemeet moet word as beskrywing van die kriteriumkonstruk werksukses ( $\eta$ ) (Lengnick-Hall, 1994; Milkovich \& Boudreau, 1994). Dit is egter ' $n$ onuitvoerbare strategie, siende dat keuring ' $n$ voorvereiste vir die meting van prestasie is, weens die natuurlike tydsvolgorde tussen aanstelling en prestasiebeoordeling (Brogden, 1949; Lengnick-Hall, 1994). Weens die onuitvoerbaarheid van dié ideaal moet die kriteriumkonstruk nou, as alternatiewe strategie, indirek beraam 
word. Dit geskied deur middel van 'n substituut vir die kriteriumkonstruk $(\eta)$, wat wel ten tye van die keuringsbesluit gemeet kan word en wat kriteriumgerig geïnterpreteer kan word. Die fokus van personeelkeuring bly naamlik steeds die kriteriumkonstruk, werksukses. Dit is egter slegs moontlik indien, en die mate waartoe, daar ten eerste ' $n$ sistematiese verwantskap tussen die kriterium en die substituut bestaan (Binning \& Barrett, 1989). Ten einde substituutmetings kriteriumgerig te kan interpreteer, moet die aard van die verwantskap egter ten tweede ook bekend wees.

Slegs twee benaderings bestaan om sodanige substituutkonstrukte en metings te genereer, naamlik ' $n$ konstrukgeoriënteerde en ' $n$ inhoudsgeoriënteerde benadering (Binning \& Barrett, 1989; Cascio, 1998; Roe, 1998; SIP, 1998). Beide benaderings is gebaseer op die veronderstelling dat verskille/variansie in werksprestasie ( $\eta$ ) die resultaat is van die wetmatige werking van 'n komplekse interafhanklike netwerk van situasionele en persoongesentreerde determinante $(\xi)$. Die konstrukgeoriënteerde benadering tot keuring beteken dat keuring gebaseer word op metings (X) van persoongesentreerde eienskappe $(\xi)$, wat teoreties en logies sistematies verband hou met werksgedrag (werksukses) (Binning \& Barrett, 1989; Cascio, 1998; Roe, 1998; SIP, 1998). Die persoonseienskappe word dus gemeet as voorspellers van werksukses. Die inhoudsgeoriënteerde benadering tot keuring daarenteen behels dat keuring gebaseer word op waarneembare gedrag of bevoegdhede (X), wat indien dit in die werkskonteks getoon sou word, geag sou word as suksesvolle werksprestasie (Binning \& Barrett, 1989; Cascio, 1998; Roe, 1998; SIP, 1998). Die waarneembare gedrag word tipies ontlok deur gesimuleerde posvereistes en dien ook as voorspellers van werksukses. Die waarneembare gedrag verteenwoordig in effek waarneembare manifestasies van die kriteriumkonstruk $(\eta)$ en word steeds gedetermineer deur 'n komplekse netwerk van (egter nou onbekend) persoongesentreerde eienskappe $(\xi)$.

Die vlak van $\eta$ kan uit $X$ afgelei word in die mate waartoe $X$ ' $n$ geldige voorspeller van $\eta$ is. Die substituut informasie (X) kan as ' $\mathrm{n}$ geldige voorspeller geag word in die mate waartoe dit ' $\mathrm{n}$ suiwer en volledige verklaring van die variansie in werksukses $(\eta)$ gee. Om die geldigheid van ' $n$ keuringsprosedure as voorspeller van $\eta$ te demonstreer, behels egter meer as bloot die toepassing van een van die drie valideringstrategieë wat tradisioneel onderskei word (konstruk-, inhouds- en kriteriumverwante geldigheid). Al drie die strategieë is relevant en moet op 'n geintegreerde wyse figureer in die argument in terme waarvan die toelaatbaarheid van die kriteriumgerigde (dus ${ }^{*}{ }_{2}$-gerigde) interpretasie van $\mathrm{X}$ aangetoon word (Arvey \& Faley, 1992; Binning \& Barrett, 1989; Campbell, 1990; Cascio, 1998; EEOC, 1978; SIP, 1998). Die geldigheid van die keuringsprosedure $(\mathrm{X})$ as voorspeller van $\eta$ kan per implikasie slegs aanvaar word indien drie verbande empiries oortuigend gedemonstreer word. Die struktuur waarbinne die drie verbande gedemonstreer word, word daargestel deur 'n volledig gedefinieerde prestasie-hipotese en prestasiedomein wat direk verband hou met die posbeskrywing afgelei uit 'n sistematiese posontleding (Algera \& Greuter, 1998; Binning \& Barrett, 1989; Cascio, 1998; de Wolff \& van den Bosch, 1998; Milkovich \& Boudreau, 1994; Thorndike, 1982). Eerstens moet gedemonstreer word dat die substituutinformasie (X) konstrukgeldige metings van die afgeleide konstrukte $(\xi)$ gee, wat in terme van die prestasiehipotese sal lei tot werksukses (konstrukgeoriëntreerde benadering); of dat X ' $\mathrm{n}$ verteenwoordigende steekproef van die posvereistes is, wat gesamentlik die posinhoud verteenwoordig $(\xi)$ (inhoudsgeoriënteerde benadering). Dit word voorgestel as verband a in figuur 1 . Tweedens moet gedemonstreer word dat die meting van werksukses $(\mathrm{Y})$ wel konstrukgeldige metings van die konstruk werksukses $(\eta)$ verskaf. Dit word voorgestel as verband $\mathrm{b}$ in figuur 1 . Laastens moet gedemonstreer word dat die voorspelde prestasiemetings $(\mathrm{E}[\mathrm{Y} \mid \mathrm{X}])$, afgelei uit $\mathrm{X}$, beduidend variansie in die metings van werksukses $(\mathrm{Y})$ verklaar, dus dat $\mathrm{X}$ beduidend (positief/negatief) korrelleer met Y (Binning \&
Barrett, 1998; Campbell, 1990; Cascio, 1998; de Wolff \& van den Bosch, 1998; Dulewics \& Fletcher, 1987; EEOC, 1978; Guion, 1991, 1995; Thorndike, 1982; Toplis). Dit word voorgestel as verband c in figuur 1. Indien hierdie drie verbande oortuigend gedemonstreer is, kan die vlak van $\eta$ per implikasie geldig (dus toelaatbaar) vanuit $X$ afgelei word (verband d in figuur 1). Anders gestel, alleenlik indien daar steun vir al drie die verbande bestaan, mag die voorspelde prestasietelling $(\mathrm{E}[\mathrm{Y} \mid \mathrm{X}])$ as ' $\mathrm{n}$ benaderde uitbeelding van uiteindelike werksprestasie beskou word.

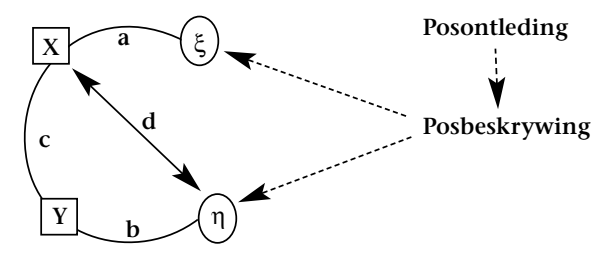

Figuur 1: Skematiese voorstelling van die afleidings wat regverdig moet word in 'n geldigheidstudie

Waar:

$X=$ metings van $\xi$ waaruit voorspellings van $\eta$ linieêr afgelei word om te dien as substituutinformasie van werksukses.

$\xi=$ substitute vir werksukses/afgeleide konstrukte of geidentifiseerde bevoegdhede/gedrag wat sal lei tot werksukses.

$\mathrm{Y}=$ metings $\operatorname{van} \eta$

$\eta=$ werksukses/prestasiedomein/kriteriumkonstruk.

Die voorspeller/substituutinformasie van werksukses (X) kan in terme van twee strategieë versamel en gekombineer word (Cascio, 1998; Lengnick-Hall, 1994):

- Meganiese data insameling: Die verkryging van objektiewe informasie deur byvoorbeeld psigometriese toetse te gebruik.

- Subjektiewe data insameling: Waar data deur menslike opinie verkry word; byvoorbeeld onderhoude.

- Meganiese data kombinering: Kombineer data met behulp van ' $n$ formele, eksplisiet geformuleerde besluitnemingsreël; ' $n$ formule wat deurgaans gebruik word om besluite op te baseer.

- Subjektiewe data kombinering: Data word subjektief gekombineer deur die besluitnemer met behulp van ' $n$ implisiete, nie-formeel omskrewe besluitnemingsreël.

'n Verskeidenheid van studies (Lengnick-Hall, 1994; Wiggens, 1973) het deurslaggewend bewys dat data meganies of meganies en subjektief versamel moet word, maar dat data beslis meganies gekombineer moet word vir die mees effektiewe keuringsbesluitneming.

In die lig van bogenoemde word 'n aktuariële benadering tot keuring voorgestel, waarvolgens 'n meganiese besluitnemingsreël afgelei word uit historiese data van werklike prestasie $(\eta$ betroubaar en geldig gemeet deur Y) en metings van die substitute van werksukses ( $\xi$ betroubaar en geldig gemeet deur $X$ ), afgelei uit die posbeskrywing. Die meganiese besluitnemingsreël word of deur ' $n$ huidige werknemersvalideringsmetode, of ' $n$ opvolgvalideringsmetode, verkry (Cascio, 1998; Guion, 1991; Schmitt, Gooding, Noe \& Korsch, 1984; SIP, 1998; Toplis et al, 1987). Die besluitnemingsreël reguleer die toewysing van applikante aan behandelings (Cronbach \& Gleser, 1965) op grond van voorspelde prestasie $(\mathrm{E}[\mathrm{Y} \mid \mathrm{X}])$ afgelei uit die beskrywing van die sistematiese verwantskap tussen $\mathrm{Y}$ en metings van voorspellerkonstrukte $(\mathrm{X})$. 'n Skematiese uitbeelding van die stappe ter sprake in die aktuariële benadering tot keuring word weergegee in figuur 2 .

$\mathrm{Al}$ is ' $\mathrm{n}$ keuringsprosedure geldig (in die sin dat afleidings aangaande die kriteriumkonstruk ( $\eta$ ) uit metings van die voorspellerkonstrukte (X) toelaatbaar is), kan dit steeds die lede van die onderskeie subgroepe waaruit die applikantepopulasie bestaan (ras en/of geslag), met gelyke waarskynlikheid op sukses, se waarskynlikheid op sukses differensiëel voorspel. Die aktuariële benadering tot keuring vereis gevolglik ook dat ' $n$ 
billikheidstudie onderneem word om te bepaal of die aktuarieel afgeleide besluitnemingsreël eenvormig gebruik kan word sonder dat daar teen ' $n$ bepaalde subgroep onbillik gediskrimineer word. Die billikheid van ' $n$ keuringsprosedure is egter ' $n$ ingewikkelde en ontwykende konsep siende dat dit die etiese/morele aspek van keuring verteenwoordig en gereguleer word deur organisatoriese waardes en anti-diskriminasie en regstellende aksie wetgewing. Daar is baie alternatiewe modelle waarvolgens die billikheid van keuringsprosedures geëvalueer kan word, wat gebaseer is op verskillende, soms teenstrydige statistiese definisies van billikheid. Vir elke model/statistiese definisie word daar sekere praktiese implikasies of oplossings voorgestel oor hoe ' $n$ keuringsprosedure billik toegepas kan word (Cascio, 1982, 1998; Peterson \& Novick, 1976). Volgens Cleary (1968) is ' $n$ keuringsprosedure onbillik as 'n eenvormige besluitnemingsreël sistematies nie-zero voorspellingsfoute maak wat verband hou met groeplidmaatskap. 'n keuringsprosedure is ingevolge dié siening dus onbillik as die kriteriumprestasie wat voorspel word van 'n gemeenskaplike kleinste kwadrate regressievergelyking sistematies te hoog of te laag is, vir die lede van 'n subgroep (Cascio, 1982, 1998; EEOC, 1978; Peterson \& Novick, 1976; Schepers, 1996; Schmitt, 1995).

Alle menslike hulpbronaktiwiteite moet uiteindelik bydra tot die organisatoriese einddoelwit naamlik die maksimering van wins. Met arbeidskoste wat tipies die grootste proporsie van totale koste uitmaak, is dit logies dat menslike hulpbronintervensies (byvoorbeeld keuring) geregverdig moet word deur die winsgewendheid daarvan te demonstreer. Die investering in die ontwerp, implementering en onderhoud van die intervensies moet genoegsame opbrengs toon om sin te maak. Die menslike hulpbronfunksie moet dus met behulp van toepaslike finansiële indikatore (byvoorbeeld koste, toename in produktiwiteit/ uitsette en opbrengs op investering) aantoon dat die intervensie waarde toevoeg tot die organisasie. Die aktuariële benadering vereis dus ook dat 'n nutwaardestudie onderneem moet word om die relatiewe nutwaarde van 'n keuringsprosedure te bepaal, sodat dit regverdig kan word teenoor alternatiewe strategieë, vir die bereiking van organisatoriese doelwitte (Cascio, 1991; SIP, 1998). Nutontleding verwys na die proses wat beskryf, voorspel en/of verduidelik wat die bruikbaarheid/aantreklikheid van besluitnemingsopsies is en ontleed hoe die informasie gebruik kan word in besluitneming. Nutontleding is dus die wyse waarop die substansiële waarde van besluitnemingsopsies beter verstaan kan word, vir beter besluitneming deur menslike hulpbronbestuur (Boudreau, 1991; 1995).

In die konteks van personeelkeuring verwys nutontleding na ' $\mathrm{n}$ aantal spesifieke modelle wat die gevolge (gewoonlik prestasieverwant) van keuringsprosedures bepaal en verwys nut na die verbetering in die kwaliteit van die geselekteerdes, weens die gebruik van die keuringsprosedure (Boudreau, 1991; 1995; Cascio, 1991; 1998). Die onderskeie nutmodelle definieer die kwaliteit van werknemers verskillend (Cascio, 1991; 1998):

- Die proporsie suksesvol gekeur; suksesratio (Taylor-Russell Model).

- Die gemiddelde standaardtelling van die geselekteerde groep op die kriterium (Nylor-Shine Model).

- Die rand/sent $(\mathrm{R} / \mathrm{c})$ waarde van die verbetering in prestasie teweeggebring deur die gebruik van die keuringsprosedure (Brogden-Cronbach-Gleser Model)
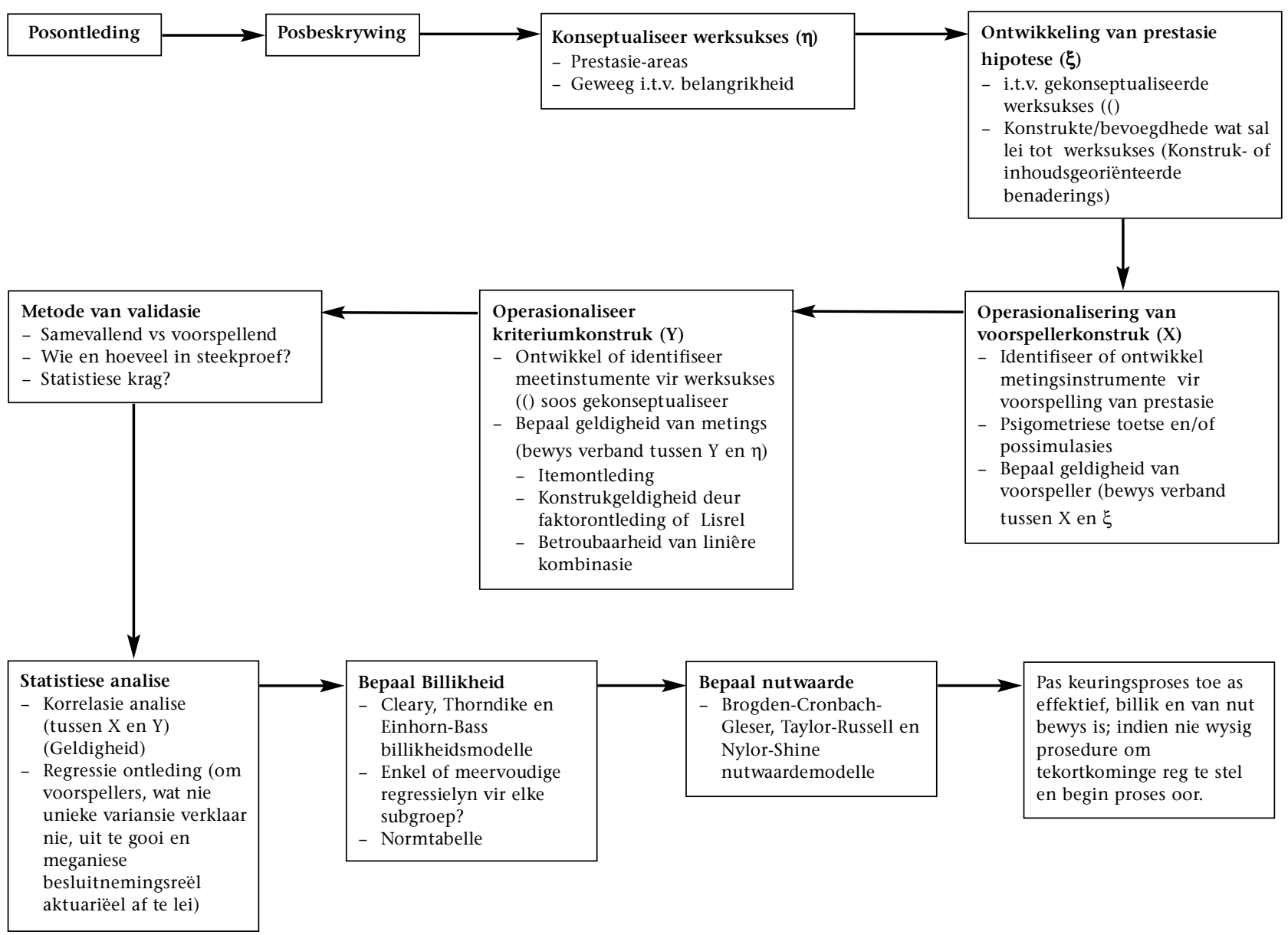

Figuur 2: Die aktuariële benadering tot die ontwikkeling en regverdiging van ' $n$ keuringsprosedure 


\section{DIE ONTWIKKELING EN EVALUERING VAN DIE KEURINGSPROSEDURE VIR DIE KEURING VAN KOMMISSIE-ADVISEURS}

Die keuringsprosedure vir die keuring van kommissie-adviseurs is gebaseer op ' $n$ erkende sistematiese en deeglike posontleding, die Pat Mcclagan posontledingsmetode. Die posontleding is gedokumenteer en onderneem deur takbestuurders en streeksbestuurders, wat as kundiges in die posveld geag word. ' $\mathrm{n}$ Posbeskrywing is saamgestel en gedokumenteer wat gebaseer is op die posontleding.

Die keuringsprosedure behels ' $\mathrm{n}$ paneelonderhoud wat bevoegdheidsgerig is en ten doel het om die minimum posvereistes te identifiseer. Verder word ' $\mathrm{n}$ takseersentrum (inhoudsgeoriënteerde benadering) gebruik wat bestaan uit vyf oefeninge (kliënte onderhoud; telefoon-afspraak; onderhoud met bestuurder; posmandjie, en wanbetaling - in rangorde van belangrikheid). $\mathrm{Na}$ afloop van elke oefening moet die beoordelaars ' $\mathrm{n}$ indrukspunt (volgens ' $\mathrm{n}$ 4-punt Likertskaal) toeken aan onderskeidelik tien bevoegdhede (besigheidsoriëntasie; netheid en akkuraatheid; kliënte diensoriëntasie; aanbiedingsvaardighede; probleem-identifisering en oplossing; selfvertroue en impak; verhoudingsbou; prestasie oriëntasie; proaktiwiteit, en interpersoonlike sensitiwiteit). Die vyf metings van elke bevoegdheid word subjektief gekombineer om ' $\mathrm{n}$ algehele bevoegdheidspunt te verkry en die algehele bevoegdheidspunte word ook subjektief gekombineer om 'n algehele aanbeveling (nie-aanbeveel; voorwaardelik-aanbeveel; aanbeveel, en sterk-aanbeveel) te verkry. Die takseersentrum word onderneem deur twee beoordelaars, tipies keuringskonsultante met ervaring in beoordeling, wat weekliks vergader in ' $n$ poging om die beoordelings te standaardiseer. Die bevoegdhede en oefeninge is geïdentifiseer vanuit die posontleding deur takbestuurders en streeksbestuurders, wat volgens hul ekspert opinie relevant is tot werksukses, of werksukses tot gevolg het.

Werksukses word egter slegs in terme van 'n GEM-telling ('n rekenkundige berekening van die $\mathrm{R} / \mathrm{c}$-waarde per maand van ' $\mathrm{n}$ werknemer vir die onderneming) gedefinieer, waar 'n GEMtelling onder R5 000 ' $\mathrm{n}$ verlies impliseer vir die onderneming en bo R10 000 'n profyt. Naas die GEM-telling is twee verdere objektiewe kriteriummetings geïdentifiseer, naamlik polisse verkoop per maand en persentasie wanbetalings van polisse verkoop oor die laaste ses maande, vir die doeleindes van ' $n$ empiriese validasie van die keuringsprosedure, wat tot op hede nie onderneem is nie.

\section{METODOLOGIE}

Die evaluasie van die ontwikkelingsgeskiedenis van ' $\mathrm{n}$ keuringsprosedure geskied in wese deur dit te vergelyk met die ideale benadering tot die ontwikkeling en regverdiging van ' $\mathrm{n}$ keuringsprosedure, afgelei uit erkende standaard riglyne. Die doel van die psigometriese oudit is om enige proseduriële en substantiewe tekortkominge, wat die onderneming se vermoë om die keuringsprosedure teenoor relevante belange groepe te regverdig in die gedrang sou bring, te identifiseer en reg te stel. Dus gaan hierdie studie die wyse waarop die keuringsprosedure vir die keuring van kommissie-adviseurs ontwikkel en regverdig is, vergelyk met die ideaalbenadering aan die hand van ' $\mathrm{n}$ kontrolelys om sodanig enige proseduriële en substantiewe gebreke te identifiseer en reg te stel of ten minste aanbevelings ten opsigte van regstellings te maak.

'n Vergelyking van die ontwikkelingsgeskiedenis van die keuringsprosedure vir die keuring van kommissie-adviseurs met die ideaalbenadering soos geoperasionaliseer in die kontrolelys, toon onomwonde aan dat die empiriese validering van die keuringsprosedure ontoereikend is. Gevolglik gaan die oudit die ontwikkelingsproses voltooi deur die keuringsprosedure empiries te valideer, met die doel om uiteindelik ' $n$ meganiese besluitnemingsreël aktuarieel af te lei en te regverdig in terme van billikheid en nut. ' $n$ Steekproef van 115 huidige kommissieadviseurs, wat gedurende die laaste twee jaar in diens geneem is, se historiese voorspellerdata en kriteriummetings oor die laaste ses maande is versamel. Die voorspellerdata is wel in ag geneem by die indiensneming van die kommissie-adviseurs. Validasieontwerp vyf in die Sussman en Robertson (1986) taksonomie is dus gebruik. Daarmee ontstaan egter ' $n$ konseptuele spanning tussen die seleksieontwerp, die applikantpopulasie en die validasieontwerp wat slegs ten dele oorkom kan word deur middel van toepaslike statistiese korreksies vir die attenuerende effek van variansie-inperking en kriteriumonbetroubaarheid.

Korrelasieontledings is onderneem om die verband tussen die voorspellermetings (X) (die algehele aanbeveling; die algehele bevoegdheidspunt, en die afsonderlike bevoegdheidsmetings per oefening) en die kriteriummetings (Y) (GEM-telling; polisse per maand, en persentasie wanbetalings) te bepaal. Die resultate van die korrelasieontledings dui egter aan dat dit sinneloos sou wees om enige regressieontledings te onderneem om 'n linieêre kombinasie van voorspellers te probeer vind om die saamgestelde kriterium (GEM) te probeer voorspel. Gevolglik sou dit ook sinneloos wees om die billikheid van die keuringsprosedure/besluitnemingsreël te ondersoek vanuit die perspektief van ongekwalifiseerde individualisme, deur gebruik te maak van die Cleary of EinhornBass billikheidsmodelle. Die invloed van ras en geslag op die voorspellermetings en kriteriummetings is wel met behulp van ttoets en frekwensieontledings ondersoek.

Die nutwaarde van die keuringsprosedure vir die keuring van kommissie-adviseurs is ondersoek deur gebruik te maak van die Taylor-Russell en Brogden-Cronbach-Gleser nutmodelle. Die reaksie van die R/c-nut per geselekteerde bo ewekansige keuring op veranderinge in die geldigheidskoëffisiënt $\left(\mathrm{r}_{\mathrm{xy}}\right)$ en seleksieratio (SR) is verder grafies ondersoek, ter illustrasie van wat die potensiële toename in nut sal wees met ' $n$ verbeterde geldigheidskoëffisiënt.

\section{RESULTATE EN BESPREKING}

Met behulp van die kontrolelys vir die ontwikkeling en evaluering van aktuarieel ontwikkelde keuringsprosedures het verskeie tekortkominge, soos vervolgens bespreek sal word, in die ontwikkeling en evaluering van die keuringsprosedure vir die keuring van kommissie-adviseurs aan die lig gekom.

Ten opsigte van die demonstrasie van die verband tussen die takseersentrum $(\mathrm{X})$ en die bevoegdheidsdomein $(\xi)$ (inhoudsgeoriënteerde benadering) (verband a in figuur 1) is die substituutinformasie, in die vorm van die kliniese takseersentrumbeoordelings, wel gebaseer op ' $\mathrm{n}$ volledige posbeskrywing en hou die bevoegdhede geïdentifiseer deur kundiges logies en rasioneel verband met werksukses. Die teenwoordigheid van die bevoegdhede by 'n applikant behoort dus logies te lei tot toekomstige werksukses. Die oefeninge waardeur die bevoegdhede gemeet word hou ook logies verband met die tipiese kritieke aktiwiteite in kommissie-adviseurs se daaglikse werk. Die oefeninge kan dus logies en rasioneel as ' $n$ voldoende steekproef van die bevoegdhede geag word. Voorts bestaan daar ' $n$ poging om die takseersentrumbeoordelings te standaardiseer deur middel van weeklikse vergaderings en om objektiewe beoordelings te verkry deur van meervoudige beoordelaars gebruik te maak. Voorts is gevind dat die afsonderlike bevoegdheidsmetings per oefening wel beduidend inter-korreleer $(p<0.05)$ en beduidend korreleer met die algehele bevoegdheidspunte, wat 'n aanduiding van betroubaarheid en faktoriale geldigheid is.

Proseduriële tekortkominge in die takseersentrumbeoordelings 
plaas egter beduidende beperkings op die mate waartoe die verband tussen $\mathrm{X}$ en $\xi$ oortuigend gedemonstreer kan word. Die bevoegdhede omvat in die prestasie-hipotese word nooit in terme van waarneembare gedrag gedefinieer nie. Die omskrywing van die bevoeghede moet die gewensde gedrag en ongewensde gedrag vervat, sodat daar ' $\mathrm{n}$ kontrolelys saamgestel kan word wat die gewensde en ongewensde gedrag per bevoegdheid spesifiseer. Gevolglik behoort die kontrolelys gebruik te word tydens die bevoegdheidbeoordelings, met die doel dat die beoordelaars die waarneembare gedrag aftik soos hul dit waarneem. Tans word die beoordelaars se algehele indruk gebruik na afloop van elke oefening om al tien bevoegdhede te beoordeel. ' $n$ Indrukspunt maak dit onmoontlik om beoordelings voldoende te standaardiseer en objektiewe beoordelings te verkry (waar beoordelings in sy natuurlike aard subjektief is), wat tot sydigheid en kontaminasie in beoordeling lei. Itemsydigheid is nie ondersoek nie en die aanwesigheid van kontaminerende faktore is ook nie geidentifiseer en so ver moontlik beheer nie. Die beoordelings verloor dus waarskynlik akkuraatheid en geldigheid as metings van die bevoegdhede, wat die geloofwaardigheid en bruikbaarheid van die beoordelings in besluitneming beperk. Verder ontvang die beoordelaars geen of beperkte opleiding in die beoordeling van die bevoegdhede in die spesifieke takseersentrum en is hul ook nie kundig op die gedrag van die spesifieke posveld nie. Kundiges behoort opgelei te word in beoordeling, sodat die beoordelaars die gedrag in die kontrolelys van gewensde en ongewensde gedrag kan identifiseer en toepaslik kan beoordeel.

Deur middel van die takseersentrum word die beoordelings op al drie vlakke (bevoegdheidsmetings per oefening, algehele bevoegdheidspunte en algehele takseersentrumbeoordelings), aan die hand van 'n 4-punt Likertskaal gekwantifiseer. In die praktyk word slegs drie punte gebruik (geen/min sterk aanbevelings of uitstekende beoordelings word gemaak nie), wat die sensitiwiteit van die skaal onder verdenking plaas. Applikante word dus in die praktyk slegs in drie katogorieë verdeel in terme van hul voorspelde prestasie. Daar bestaan gevolglik die wesenlike moontlikheid dat persone wat in werklikheid verskil op die kriteriumkonstruk nie van mekaar onderskei kan word nie, as gevolg van die onsensitiewe aard van die voorspellerskaal. Die beperking in variansie attenueer dus die geldigheid van besluite wat gebaseer is op die beoordelings. Indien dit prakties uitvoerbaar is, behoort die beoordelings gekwantifiseer te word op 'n 7-punt of selfs 9-punt Likertskaal.

Die beoordelings word subjektief gekombineer om ' $\mathrm{n}$ algehele takseersentrumbeoordeling te verkry. Voorspellersdata behoort egter objektief gekombineer te word vir die mees geldige voorspellings, deur 'n aktuariële besluitnemingsreël gebaseer op ' $n$ regressieontleding, waar die bevoegdhede empiries bepaalde gewigte behoort te verkry volgens hul relatiewe belangrikheid ten opsigte van die voorspelling van werksukses.

Daar is geen dokumentasie of inligting beskikbaar oor die paneelonderhoude wat as siftingsproses vir die takseersentrum dien nie en dit is dus onmoontlik om die prosedure te evalueer. Die keuringsprosedure se bruikbaarheid kan dus reeds by die siftingsproses beperk word en die onderhoudbeoordelings behoort ingesluit te word by die oudit, sodat die moontlike beperkinge wat dit op die geldigheid van die keuringsprosedure sou kon hê, reg gestel kan word.

Ten opsigte van die demonstrasie van die verband tussen die kriteriummetings $(\mathrm{Y})$ en die prestasiedomein $(\eta)$ (verband $b$ in figuur 1) word daar slegs van objektiewe prestasiemetings (byvoorbeeld polisse per maand verkoop) gebruik gemaak, wat per definisie gekontamineer is. Irrelevante omgewingsinvloede (byvoorbeeld die welvaarendheid van die verkoopsgebied) word nie geïdentifiseer en in berekening gebring nie. Die kriteriumkonstruk behoort konstitutief in terme van werksgedrag gedefinieer te word, gebaseer op die posbeskrywing. Prestasie word egter slegs in terme van werksuitkomste, 'n GEM-telling groter as R10 000 per maand, gedefinieer, wat die meting van werksprestasie in terme van waarneembare werksgedrag (wat oor die minste kontaminasie en dus oor die meeste geldigheid beskik) sinneloos maak, omrede die kriterium geoperasionaliseer moet word in soortgelyke terme as dit waarin dit gedefinieer is. Die enkele en grootste gebrek in die oortuigende demonstrasie van die verband is dus dat die ontwikkeling en operasionalisering van die kriterium nie gedraggeanker is nie. Die oudit moet egter die praktiese onuitvoerbaarheid van gedraggeankerde kriteriumontwikkeling en operasionalisering erken. Kommissie-adviseurs se werk word nie by 'n sentrale werkplek verrig nie, maar by die kliënte se kantore of wonings, wat die waarneming van hul werksgedrag prakties onuitvoerbaar maak. 'n Positiewe verwantskap tussen die GEM-telling en polisse per maand, en ' $n$ negatiewe verwantskap tussen die GEM-telling en persentasie wanbetaling is onvoldoende, maar wel beperkte bewyse van geldige kriteriummetings. Verder het die kriteriummetings genoegsame diskriminerende krag en sensitiwiteit getoon. Alhoewel die GEM-tellings skeef na regs verdeel is toon die kriteriumprestasie tog ' $\mathrm{n}$ relatiewe hoë standaardafwyking naamlik, R6 782 per maand.

Geen statisties beduidendende verband is tussen die klinies afgeleide aanbevelings uit die takseersentrumbeoordelings (X) en die GEM-telling (Y) (verband $\mathrm{c}$ in figuur 1) gevind nie ( $p>0.05$ ). Geen statisties beduidende verband tussen enige van die algehele bevoegdheidspuntbeoordelings en die saamgestelde kriterium $(\mathrm{Y})$ is gevind nie. Daar is ook nie enige statisties beduidende veband tussen die afsonderlike bevoegdheidsmetings per oefening en $\mathrm{Y}$ gevind nie, met die enkele uitsondering van aanbiedingsvaardighede gemeet deur die kliënte onderhoudsoefening, met 'n marginaal statisties beduidende $(\mathrm{p}<0.1)$ korrelasie van 0.18 . Dit kan egter, in die lig van die res van die bevindinge, as ignoreerbaar geag word. Siende dat daar nie ' $n$ beduidende verband tussen enige voorspeller en die saamgestelde kriterium gevind is nie, sou dit sinneloos wees om deur middel van regressieontledings ' $n$ geweegde linieêre kombinasie van voorspellers te probeer vind wat die kriterium optimaal voorspel. Dit sou onder hierdie omstandighede ook sinneloos wees om die billikheid van ' $\mathrm{n}$ besluitnemingsreël formeel te ondersoek. Daar is dus geen empiriese grondslag vir ' $n$ aktuariële besluitnemingsreël nie. Verder is daar statisties beduidende $(\mathrm{p}<0.05)$ verbande tussen die afsonderlike bevoegdhede se algehele bevoegdheidspunte gevind, terwyl byvoorbeeld ' $\mathrm{n}$ prestasieoriëntasie en verhoudingsbou nie noodwendig verband behoort te hou nie, wat die moontlikheid van ' $\mathrm{n}$ stralekranseffek op die beoordelings voorstel.

Die keuringsprosedure vir die keuring van kommissie-adviseurs kan dus as onbillik geag word, beskou vanuit ' $n$ ongekwalifiseerde individualistiese oogpunt, siende dat die keuringsbesluit in effek ewekansig geskied. Keuring geskied dus nie op gronde van inherente vereistes van die pos nie en wetgewing sal die keuringsprosedure vir die keuring van kommissie-adviseurs as onbillik diskriminerend beskryf. Deur middel van ' $\mathrm{n}$ t-toets is empiries aangetoon dat die bevoorregte (blanke) groep gemiddeld ongeveer R4 000 per maand hoër presteer $(\mathrm{p}<0.05)$ op die GEM as die histories benadeelde groep. Hierdie beduidende verskil in kriteriumprestasie is waarskynlik ' $\mathrm{n}$ nalatenskap van apartheid, maar sou andersyds ook verklaar kon word in terme van sydigheid in die kriteriummetings. Indien geldige voorspellerdata op ' $\mathrm{n}$ billike wyse kriteriumgerig geinterpreteer word, moet ' $n$ situasie soos hierdie noodwendig lei tot nadelige impak ten opsigte van die groep wat laer presteer op die kriterium ongeag die aard van die groepe se voorspellerverdelings. Indien die eersgenoemde verklaring as geldig beskou word, beklemtoon dit die noodsaaklikheid om potensiaal onder kommissie-adviseurs uit agtergeblewe groepe te identifiseer en deur middel van versnelde leer te ontwikkel. Geen beduidende verskil in gemiddelde GEM-telling ( $p>0.05)$ is ten opsigte van geslag gevind nie. Kruistabulasie van die aanbeveling, klinies afgelei uit die resultate van die takseersentrum, met geslag 
en ras respektiewelik, toon swak en onbeduidende verwantskappe ( $>0.05)$ tussen groeplidmaatskap en die klinies saamgestelde voorspellerdata. Die nulhipotese van geen groepeffek op die tien algehele bevoegdheidspunte is met behulp van eenrigting MANOVA's ondersoek en kan in die geval van ras sowel as geslag nie verwerp word nie ( $p>0.05)$. Die ironie is gevolglik dat daar eintlik geen prima facie gronde vir onbillike diskriminasie bestaan waarop die de facto diskriminerende prosedure formeel via litigasie tot verantwoording geroep sou kon word nie.

Die nutwaarde van die keuringsprosedure vir die keuring van kommissie-adviseurs in terme van die Taylor-Russell model is zero, siende dat die suksesratio en basisratio dieselfde is (weens die $r_{x y}$ van zero) en gelyk aan 0.33. In die mate waartoe die suksesratio en basisratio weg beweeg van mekaar verhoog die nutwaarde in terme van die Taylor-Russell model. Die nutwaarde sal dus toeneem soos die $r_{x y}$ toeneem en die seleksieratio afneem (Boudreau, 1991; 1995; Cascio, 1991; 1998). Die Taylor-Russell model wys egter dat voorspellers met lae geldigheid substansiële toename in die suksesratio kan bewerkstellig, indien die seleksieratio klein is (Cascio, 1991; Schmidt, Hunter, McKenzie \& Muldrow, 1979). Soortgelyk is die nutwaarde van die keuringsprosedure, beskou vanuit die Naylor-Shine interpretasie, ook zero.

Die nutwaarde van die keuringsprosedure vir die keuring van kommissie-adviseurs in terme van die Brogden-CronbachGleser model word in figuur 3 geïllustreer as ' $n$ funksie van die geldigheid en seleksieratio van die keuringsprosedure. Die toename in R/c nutwaarde per geselekteerde bo ewekansige keuring is ondersoek met die aanname van ' $\mathrm{n}$ gemiddelde dienstermyn van drie jaar en die $\mathrm{R} / \mathrm{c}$ waarde van een standaardafwyking in prestasie gelyk aan die standaardafwyking van die GEM-telling naamlik, R6 782 per maand. Die koste om een applikant deur die takseersentrum te sit is R1 700. Vir die Brogden-Cronbach-Gleser model is die netto nut per geselekteerde ingewin deur die eenmalige gebruik van die takseersentrum (Arvey \& Faley, 1992; Boudreau, 1991; 1995; Cascio, 1991; 1998; Cook, 1998; Schmidt et al., 1979):

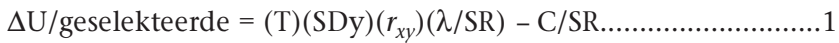

Waar: $\Delta \mathrm{U} /$ geselekteerde $=$ Die geldwaarde $(\mathrm{R} / \mathrm{c})$ van die toename in prestasie per geselekteerde deur die eenmalige gebruik van die keuringsprosedure bo ewekansige keuring.

$\mathrm{T}=\quad$ Die verwagte gemiddelde dienstermyn van die geselekteerde groep.

SDy $=$ Die geldwaarde van een standaardafwyking in werksprestasie.

$r_{x y}=$ Die korrelasie van die keuringsprosedure met werksprestasie in die applikant groep.

$\mathrm{C}=\quad$ Die koste om een applikant te toets.

$\lambda=\quad$ Die hoogte van die ordinaat onder die normaalverspreiding by die voorspellerafsnypunt.

$\mathrm{SR}=$ Die seleksieratio

Die respons van die per geselekteerde nut op veranderinge in die geldigheidskoëffisiënt $\left(r_{x y}\right)$ en die seleksieratio (SR) is met behulp van 'n SAS-program (SAS Institute, 1991) ondersoek deur alle moontlike kombinasies van 'n steekproef geldigheids-koëffisiëntwaardes $(0.0-0.9$ in stappe van 0.05$)$ en seleksieratiowaardes $(0.1 ; 0.2 ; 0.3$, en 0.4$)$ in vergelyking ( in te voer. Die gedrag van $\Delta U /$ geselekteerde in 'n ruimte gedefinieer deur $0 \leq r_{x y} \leq 0.9$ en $0.1 \leq \mathrm{SR} \leq 0.4$ word voorgestel in figuur 3.

Die takseersentrum vir die keuring van kommissie-adviseurs toon ' $\mathrm{n}$ negatiewe nutwaarde per geselekteerde van - R17 000 vir ' $\mathrm{n} S \mathrm{SR}=0.1$ en $-\mathrm{R} 4250$ vir ' $\mathrm{n} \mathrm{SR}=0.4$. Die onderneming verloor dus geld deur die gebruik van die takseersentrum vir die keuring van kommissie-adviseurs. Figuur 3 illustreer die potensiële nutwaarde per geselekteerde van die gebruik van die takseersentrum indien daar in die toekoms ' $\mathrm{n}$ hoër $r_{x y}$ verkry sou word, deur die voorheen genoemde tekortkominge reg te stel. Met 'n relatiewe lae $r_{x y}$ van 0.25 en 'n gemiddelde $\mathrm{SR}=0.3 \mathrm{kan}$ die onderneming reeds ongeveer R50 000 per geselekteerde oor die drie jaar dienstermyn verdien, deur die gebruik van ' $n$ verbeterde takseersentrum, en sal dit relatief maklik bereik kan word deur enkele regstellings te onderneem. Vir al die SR's sal 'n minimale $r_{x y}=0.05$ reeds voldoende wees om gelyk te breek met die koste van die takseersentrum, maar sal ' $\mathrm{n} r_{x y}=0.15$ tot 0.25 vir die onderskeie SR's lei tot die keuring van winsgewende/ suksesvolle werknemers. Die gemiddelde GEM-telling van die applikante groep (R8 686) is R1 314 laer as die R10 000 GEMtelling per maand winsgewendheidsvlak en dus word ' $\mathrm{n}$ nutwaarde van R47 340 per geselekteerde oor die drie jaar dienstermyn vereis om 'n R10 000 GEM-telling per maand te impliseer. Figuur 3 illustreer duidelik dat indien die $r_{x y}$ toeneem en SR afneem sal die $\Delta \mathrm{U} /$ geselekteerde dramaties toeneem. By baie lae waardes van SR raak die verhouding C/SR egter sodanig groot dat nut negatief geaffekteer sou word.

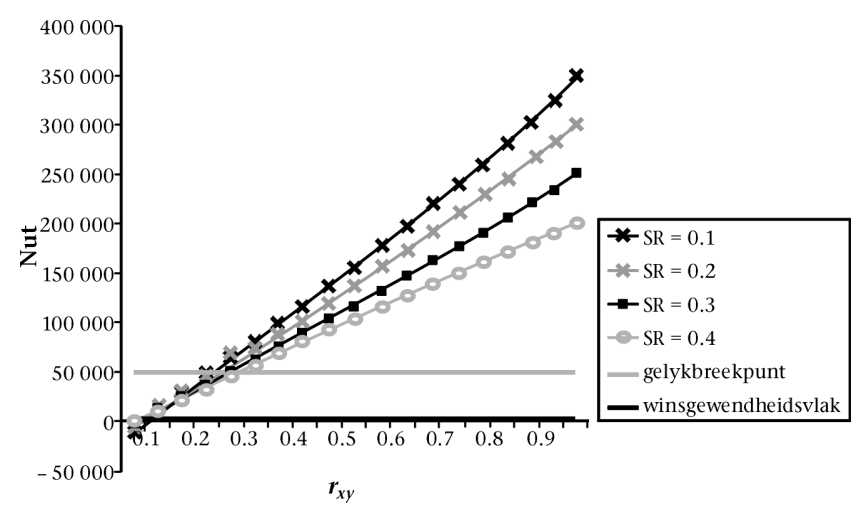

Figuur 3: Die nut per geselekteerde as ' $n$ funksie van die waarde van die geldigheidskoëffisient en die seleksieratio

\section{GEVOLGTREKKING}

Die einddoel van personeelkeuring is om waarde tot die onderneming toe te voeg deur die vlak van werksprestasie gelewer deur werknemers te verhoog deur die kwaliteit van werknemers wat deur die onderneming beweeg te verhoog. Die keuringsprosedure vir die keuring van kommissie-adviseurs voeg nie waarde toe tot die onderneming nie; inteendeel die gebruik van die takseersentrum kos die onderneming geld. Die takseersentrum verhoog ook nie die vlak van werksprestasie bo dit wat deur ewekansige keuring bereik sal word nie, siende dat daar geen verband bestaan tussen die takseersentrumbeoordelings en werksprestasie nie.

Die prosedure behoort onmiddellik gestaak te word siende dat die keuringprosedure nie bydra tot die bereiking van organisatoriese doelwitte nie, dit onbillik is en oor negatiewe nutwaarde beskik. Die keuringsprosedure vir die keuring van kommissie-adviseurs het gevolge wat strydig is met die belange van die gemeenskap en die aandeelhouers van die onderneming. Verdere gebruik van die takseersentrum kan tot ernstige regsgevolge lei, aangesien dit nie in ooreenstemming met anti-diskriminasie en regstellende aksie wetgewing geskied nie.

Die tekortkominge soos vroeër bespreek, behoort oorweeg en reg gestel te word, waarna die ontwikkeling en regverdiging van 
die verbeterde keuringsprosedure geëvalueer moet word deur dit te vergelyk met die kontrolelys vir die ontwikkeling en evaluering van aktuarieel ontwikkelde keuringsprosedures.

\section{VERWYSINGS}

Algera J.A. \& Greuter M.A.M. (1998). Job Analysis. In P.J.D. Drenth, H. Thierry \& C.J. de Wolff (Eds.). Handbook of Work and Organizational Psychology. Volume 3: Personnel Psychology (Tweede uitgawe). Hove: Psychology Press.

Arvey, R.D. \& Faley, R.H. (1992). Fairness in Selecting Employees (Tweede uitgawe). New York: Addison-Wesley Publishing Company.

Basson, A., Christianson, M., Garbers, C., le Roux, P.A.K., Mischke, C. \& Strydom, E.M.L. (1998). Essential Labour Law Volume 1: Individual Labour Law. Groenkloof: Labour Law Publications.

Binning, J.F. \& Barrett, G.V. (1989). Validity of personnel decisions: A conceptual analysis of the evidential bases. Journal of Applied Psychology, 74 (3), 478-494.

Boudreau, J.W. (1991). Utility analysis for decisions in human resource management. In M.D. Dunette \& L.M. Hough (Eds.). Handbook of Industrial and Organizational Psychology. California: Consulting Psychologists Press.

Boudreau, J.W. (1995). Selection utility analysis: A review and agenda for future research. In M. Smith \& I.T. Robertson (Eds.). Advances In Selection and Assessment. Chichester: John Wiley \& Sons.

Brogden, H.E. (1949). On the interpretation of the correlation coefficient as a measure of predictive efficiency. Journal of Educational Psychology, XXXVII (2), 65-76.

Campbell, J.P. (1990). Modeling the performance prediction problem in industrial and organizational psychology. In M.D. Dunette \& L.M. Hough (Eds.). Handbook of Industrial and Organizational Psychology. California: Consulting Psychologists Press.

Cascio, W.F. (1982). Applied Psychology in Personnel Management. Virginia: Reston Publishing Company Inc.

Cascio, W.F. (1991). Costing Human Resources: The Financial Impact of Behavior in Organizations (Derde Uitgawe). Boston: PWS-Kent Publishing Company.

Cascio, W.F. (1998). Applied Psychology in Human Resource Management (Vyfde uitgawe). London: Prentice Hall.

Cook, M. (1998). Personnel Selection: Adding Value through People (Derde uitgawe). Chichester: John Wiley \& Sons.

Cronbach, L.J. \& Gleser, G.C. (1965). Psychological Tests and Personnel Decisions. Urbana: University of Illinois Press.

De Wolff, C.J. \& van den Bosch, G. (1998). The selection process. In P.J.D. Drenth, H. Thierry \& C.J. de Wolff (Eds.). Handbook of Work and Organizational Psychology. Volume 3: Personnel Psychology (Tweede uitgawe). Hove: Psychology Press.

Equal Employment Opportunity Commission. (1978). The Uniform Guidelines on Employment Selection Procedures. Washington: Federal Register.

Gatewood, R.D. \& Feild, H.S. (1994). Human Resource Selection (Derde uitgawe). New York: Harcourt Brace College Publishers.

Grondwet van die Republiek van Suid Afrika. (1996). Staatskoerant van die Republiek van Suid Afrika, 18 Desember (no. 17678). Kaapstad: Creda.

Guion, R.M. (1991). Personnel assessment, selection, and placement. In M.D. Dunette \& L.M. Hough (Eds.). Handbook of Industrial and Organizational Psychology. California: Consulting Psychologists Press.

Guion, R.M. (1995). Comments on personnel selection methods. In M. Smith \& I.T. Robertson (Eds.). Advances In Selection and Assessment. Chichester: John Wiley \& Sons.

Hunter, J.E. \& Schmidt, F.L. (1995). Meta-analysis: facts and fiction. In M. Smith \& I.T. Robertson (Eds.). Advances In Selection and Assessment. Chichester: John Wiley \& Sons.

Lengnick-Hall, M. (1994). Strategies for selection decisionmaking. In R.D. Gatewood \& H.S. Feild. Human Resource Selection (Derde uitgawe). New York: Harcourt Brace College Publishers.

Milkovich, G.T. \& Boudreau, J.W. (1994). Human Resource Management (Sewende uitgawe). Boston: Irwin.

Psychometric Assessment Initiative. (1998). Code of Practice for Psychological Assessment for the Workplace in South Africa. Pretoria: Society for Industrial Psychology.

Peterson, N.S. \& Novick, R. (1976). An evaluation of some models for culture-fair selection. Journal of Educational Measurement, 13 (1), 3-29.

Roe, R.A. (1998). Personnel selection: principles, models and techniques. . In P.J.D. Drenth, H. Thierry \& C.J. de Wolff (Eds.). Handbook of Work and Organizational Psychology. Volume 3: Personnel Psychology (Tweede uitgawe). Hove: Psychology Press.

SAS Institute (1991). SAS/STAT. User's guide release 6.03 edition. Cary, NC: SAS Institute, Inc.

Schepers, J.M. (1996). The development of a statistical procedure to correct the effects of restriction of range on validity coefficients. Journal of Industrial Psychology, 22 (1), 19-27.

Schmidt, F.L., Hunter, J.E., McKenzie, R.C. \& Muldrow, T.W. (1979). Impact of valid selection procedures on work-force productivity. Journal of Applied Psychology, 64 (6), 609-626.

Schmitt, N. (1995). Fairness in selection. In M. Smith \& I.T. Robertson (Eds.). Advances In Selection and Assessment. Chichester: John Wiley \& Sons.

Schmitt, N., Gooding, R.G., Noe, R.A. \& Korsch, M. (1984). Meta analysis of validity studies published between 1964 and 1982 and the investigation of study characteristics. Pesonnel Psychology, 37, 407-422.

Sidiripoulos, E., Jeffery, A., Mackay, S., Forgey, H., Chipps, C. \& Corrigan, T. (1997). South African Survey 1996/97. Johannesburg: South African Institute of Race Relations.

Society of Industrial-Organizational Psychology. (1987). Principles for the Validation And Use Of Personnel Selection Procedures (Derde uitgawe). College Park, MD: Auther.

Society for Industrial Psychology. (1998). Guideline for the Validation and Use of Assessment Procedures for the Workplace. Pretoria: Psychological Society of South Africa.

Sussman, M. \& Robertson, D.U. (1986). The validity of validity: an analysis of validation study designs. Journal of Applied Psychology, 71 (3), 461-468.

Thorndike, R.L. (1982). Applied Psychology. Boston: Houghton Mifflin Company.

Toplis, J., Dulewics, V. \& Fletcher, C. (1987). Psychological Testing: a Practical Guide for Employers. London: Institute of Personnel Management.

Wet in die Bevordering van Gelykheid en die Voorkoming van Onbillike Diskriminasie. (2000). Staatskoerant van die Republiek van Suid Afrika, 2 Februarie (no.4). Kaapstad: Creda.

Wet op Gelyke Indiensnemingsgeleenthede. (1998). Staatskoerant 